\title{
KAJIAN KUALITAS GAMBIR DAN HUBUNGANNYA DENGAN KARAKTERISTIK KULIT TERSAMAK
}

\section{THE STUDY OF GAMBIR QUALITY AND ITS RELATIONSHIP WITH CHARACTERISTICS OF TANNED LEATHER}

\author{
Anwar Kasim*, Alfi Asben, Sri Mutiar \\ Fakultas Teknologi Pertanian, Universitas Andalas, Kampus Limau Manis, Padang 25163, Indonesia. \\ * Penulis korespondensi. Telp.: +62 75172772 ; Fax.: +62 75172772 \\ E-mail: anwar_ks@yahoo.com
}

Diterima: 10 Maret 2015 Direvisi: 25 Mei 2015 Disetujui: 1 Juni 2015

\begin{abstract}
This study aimed to investigate the quality of gambier taken from gambier production center in West Sumatra, the characteristic of tanned leather which was tanned by gambier, and the relationship between gambier quality and tanned leather product. This study was conducted by firstly taking the samples from ten location randomly, secondly analyzing some of its characteristics, and later applicating them in leather tanning. The relationship between some gambier parameters with tanned leather was determined by linear regression. The result was finding that the quality was varied among different gambier production centers, comprise of water content, tannin level, cathecin level, ash level and water-insoluble substances. Sixty percent of production centers had given gambier which was capable to produce leather met the quality requirements. The result also found there were a strong relationship between gambier characteristics and quality of tanned leather, e.g. gambier tannin level and bondedtannin in tanned leather $(r=0.980)$, gambier catechins level and bonded-tannin in tanned leather $(r=0.967)$ and gambier ash content and bonded-tannin in tanned leather $(r=0.852)$. Highest tannin level would produce good tanned leather.
\end{abstract}

Keywords: gambier, tanning, tanned leather, the correlation.

\begin{abstract}
ABSTRAK
Penelitian ini bertujuan untuk mengetahui kualitas gambir yang diambil dari sentra produksi gambir Sumatera Barat, mengetahui karakteristik kulit tersamak yang disamak menggunakan gambir tersebut dan mengetahui hubungan kualitas gambir dengan kulit tersamak yang dihasilkan. Penelitian dilakukan dengan mengambil sampel dari sepuluh lokasi secara acak, dilanjutkan dengan analisis karakteristik gambir serta aplikasinya dalam penyamakan kulit. Untuk mengetahui hubungan antara beberapa parameter gambir dengan parameter kulit tersamak yang dihasilkan digunakan regresi linier. Hasil penelitian menunjukkan karakteristik gambir dari sentra produksi di Sumatera Barat memiliki kualitas yang bervariasi pada kadar air, kadar tanin, katekin, kadar abu dan zat tak larut air. 60\% lokasi sentra produksi memberikan gambir yang mampu menghasilkan kualitas kulit tersamak memenuhi standar mutu. Hubungan antara beberapa parameter gambir sebagai bahan penyamak dengan kualitas kulit tersamak menunjukkan hubungan yang sangat erat antara kadar tanin gambir dengan kadar tanin terikat pada kulit tersamak $(\mathrm{r}=0.980)$, kadar katekin pada gambir dengan kadar tanin terikat pada kulit tersamak $(\mathrm{r}=0.967)$, dan kadar abu pada gambir dengan kadar tanin terikat pada kulit tersamak $(\mathrm{r}=0.852)$. Tingginya kadar tanin gambir akan menghasilkan kulit tersamak yang baik.
\end{abstract}

Kata kunci: gambir, penyamakan, kulit tersamak, korelasi.

\section{PENDAHULUAN}

Gambir berasal dari ekstrak air panas dari daun dan ranting tanaman gambir (Uncaria gambir Roxb.) yang kemudian diendapkan, ditiriskan, dicetak dan dikeringkan. Proses pengekstraksian dilakukan dengan pengempaan baik secara tradi- sional maupun menggunakan alat kempa hidrolik (Kasim, 2011). Komponen kimia utama gambir adalah katekin dan tanin. Katekin merupakan monomer dari tanin dimana menurut Fengel \& Wegener (1995) jika 3 sampai 8 molekul katekin membentuk polimer maka polimer yang terbentuk 
tergolong kepada tanin, tepatnya tanin kondensasi. Tanaman ini telah banyak digunakan sebagai obat-obatan, penyamakan kulit, tinta dan zat warna. Gambir sebagian besar terdiri dari monomer flavanol seperti katekin, epikatekin dan alkaloid (Achmad et al., 2012).

Ullmanns Encyklopedie (1978) menjelaskan bahwa gambir berasal dari daun ranting tanaman belukar yang banyak tumbuh di Cina, India dan negara-negara kepulauan Malaya. Biasanya yang digunakan adalah ekstrak padat yang diolah secara setengah industri. Gambir memberikan hasil penyamakan kulit yang lunak, lembut dan warnanya terang. Penggunakan gambir sebagai bahan penyamak kulit beberapa tahun terakhir sudah menurun dengan sangat cepatnya sejak awal tahun tujuh puluhan. Tanin yang diproduksi dunia, termasuk gambir didalamnya, 90\% diantaranya digunakan sebagai bahan penyamak kulit (Lehnen, 2006).

Indonesia sebagai penghasil ekstrak gambir lebih banyak mengekspor, yang sudah berlangsung sejak akhir abad ke 18 sampai sekarang. Pada tahun 2006 Indonesia mengekspor gambir sejumlah hampir 8000 ton (BPS, 2008) dan $84 \%$ diantaranya diekspor ke India. Provinsi penghasil utama gambir adalah Sumatera Barat di samping Sumatera Utara, Sumatera Selatan, Riau dan Bengkulu. Di negara India gambir digunakan untuk penyegar mulut, campuran pada betel bite (seperti ramuan pada sirih kunyahan di Indonesia) dan bahan pewarna alami pada tekstil.

Peningkatan kebutuhan gambir Indonesia oleh India bermula sejak pembatasan penebangan pohon katha penghasil katekin sebagaimana yang terkandung dalam gambir. Gambir Indonesia sesampai di India diolah kembali dengan tujuan utama peningkatan kandungan katekin. Produk lain dari gambir Indonesia di India adalah Pan Masala yang merupakan penyegar mulut yang dijual dalam kemasan plastik. Pan Masala juga dibuat dengan berbagai komponen dan salah satunya adalah katekin (Linkenheil \& Steinmann, 1998).

Untuk menggiatkan kembali pemanfaatan gambir dalam negeri maka Kasim et al. (2013) dan Kasim et al. (2014) telah melakukan beberapa penelitian diantaranya adalah karakteristik kulit kambing pada persiapan penyamakan dengan gambir dan sifat kulit tersamak yang dihasilkan dan minimalisasi penggunaan krom pada penyamakan kombinasi krom-gambir terhadap karakteristik kulit tersamak. Dari penelitian itu disimpulkan antara lain penggunaan gambir pada penyamakan kulit kambing menghasilkan kulit tersamak yang memenuhi standar SNI. Pada penelitian tersebut, gambir diambil dari satu lokasi dan diawasi kemurniannya.

Data pemerintahan Kabupaten 50 Kota dan Pesisir Selatan menunjukkan bahwa jumlah petani yang mengusahakan gambir sekitar 9.377 kepala keluarga (KK) dengan luas tanaman 28.325 hektar (Buletin Provinsi Sumbar, 2011). Petani gambir pada umumnya melakukan budidaya gambir lebih mengandalkan kesuburan dari lahan tanpa melakukan pemupukan sehingga berpengaruh terhadap lama produksi dan kualitas dari gambir yang dihasilkan.

Mutu gambir yang terdapat di pasaran sangat beragam yang disebabkan oleh budidaya dan proses pengolahan. Perilaku petani dapat menyebabkan permasalahan mutu gambir pada tahap pengolahan diantaranya faktor tenaga kerja, bahan baku, metode kerja dan lingkungan. Faktor tenaga kerja masih rendahnya pengetahuan, kesadaran dan komitmen pengolahan gambir untuk menjaga mutu. Faktor lingkungan yang mempengaruhi kualitas gambir berasal dari tanah, area pengempaan, bak penampung getah, abu dan jelaga dari tungku area penjemuran. Fasilitas dan peralatan yang digunakan selama proses produksi juga dapat mempengaruhi mutu gambir. Aktifitas pengolahan gambir yang mempengaruhi kualitas seperti menginjak-injak daun pada saat pemadatan daun dalam wadah perebusan, penggulungan daun menjelang pengempaan, penggunaan air kelencong untuk perebusan, penambahan bahan lain seperti tanah, pasir, tanah tepung dan bubuk dari limbah gambir, pengeringan gambir dekat permukaan tanah dan proses pengeringan gambir yang tidak sempurna tidak mendukung dihasilkannya gambir dengan mutu yang baik (Kasim, 2011).

Beragamnya mutu gambir yang dihasilkan petani akan mengakibatkan beragam pula kualitas kulit tersamak nantinya. Untuk mengetahui fakta tentang kualitas gambir yang dihasilkan maka diperlukan penelitian yang dapat memberikan gambaran tentang kualitas gambir di sentra produksi gambir Sumatera Barat.

Penelitian ini bertujuan untuk mengetahui kualitas gambir yang diambil pada sentra produksi gambir, untuk mengetahui karakteristik kulit tersamak yang disamak menggunakan gambir dari sentra produksi gambir di Sumatera Barat, dan untuk mengetahui hubungan kualitas gambir terhadap kulit tersamak yang dihasilkan. 


\section{BAHAN DAN METODE Bahan Penelitian}

Bahan yang digunakan dalam penelitian ini adalah sampel gambir dari 10 lokasi yang diambil secara acak pada sentra industri gambir, kulit kambing awet garam, kapur, natrium sulfida, asam sulfat, natrium karbonat, natrium bikarbonat, asam formiat, natrium formiat, natrium hidroksida, amonium sulfat, teepol, oropon, preventol, garam, indikator MMB, N-heksan dan aquades.

\section{Peralatan Penelitian}

Drum penyamakan skala laboratorium, pisau seset, timbangan, $\mathrm{pH}$ stick, tensile strengh tester, dan peralatan gelas untuk uji kimia.

\section{Metode Penelitian}

\section{Analisis kualitas gambir}

Penelitian ini dimulai dengan analisis kimia sampel gambir dari 10 lokasi. Penentuan kualitas gambir meliputi analisis kadar air dengan metode SNI 06-0644-1989, kadar abu, kadar bahan tak larut air metode SNI 06-0563-1989, kadar tanin (Kuentzel, 1955) dan kadar katekin dengan metode SNI 01-3391-2000.

\section{Persiapan gambir sebagai bahan penyamak}

Sampel gambir dari beberapa lokasi ditepungkan dan kemudian disaring dengan saringan 60 mesh. Selanjutnya digunakan sebagai bahan penyamak kulit. Persentase penggunaan dalam penyamakan kulit dihitung berdasarkan berat kering gambir.

\section{Penyamakan kulit}

Penyamakan kulit dengan menggunakan metode drum (Kasim et al., 2013): Persiapan kulit untuk disamak yaitu: perendaman kulit, pengapuran untuk menghilangkan bulu, pembuangan bulu dan lemak menggunakan pisau seset sampai tidak ada lagi bagian lemak yang terdapat pada kulit, penimbangan bloten (berat kulit setelah pembuangan bulu dan lemak), pembuangan kapur sampai pH netral, pengikisan protein dan pencucian kulit sampai bersih. Selanjutnya proses pengasaman untuk memperoleh kulit pikel sampai $\mathrm{pH}$ larutan mencapai 3.

Kulit pikel selanjutnya disamak dengan menggunakan gambir $15 \%$, yang dihitung berdasarkan berat kulit pikel. Penyamakan dilakukan di dalam drum berputar selama 60 menit. Selanjutnya kulit diperam selama 24 jam. Kulit tersamak dicuci dari zat penyamak yang masih melekat, kemudian kulit direntang dan dikeringkan.

\section{Analisis kimia dan pengamatan sifat fisik kulit tersamak}

Analisis kimia kulit tersamak terdiri atas analisis tanin terikat dan derajat penyamakan. Pengamatan sifat fisik kulit tersamak terdiri atas pengukuran kekuatan tarik dan kemuluran kulit. Pengujian sifat kulit tersamak dilakukan di Balai Besar Kulit, Karet dan Plastik Yogyakarta.

Analisis hubungan antara kualitas gambir dengan kualitas kulit tersamak

Hubungan antara kualitas gambir dengan kualitas kulit tersamak dilakukan analisis regresi linier. Data hasil pengamatan terhadap kualitas gambir dan kualitas kulit tersamak ditampilkan dalam bentuk tabel dan dianalisis secara deskriptif.

\section{HASIL DAN PEMBAHASAN Kualitas Gambir}

Hasil analisis kimia gambir yang diambil dari sepuluh lokasi ditampilkan pada Tabel 1. Parameter yang diamati terdiri dari kadar air, kadar tanin, kadar katekin, kadar abu dan kadar zat tak larut dalam air.

Berdasarkan Tabel 1 kualitas gambir dilihat dari kadar air menunjukkan hasil yang bervariasi berkisar antara $7,63 \%$ sampai $22,31 \%$. Kadar air yang tinggi dapat menyebabkan tumbuhnya kapang dan jamur. Jika dibandingan dengan penelitian Kasim (2011) bahwa kadar air gambir pada beberapa sampel berkisar antara $12,87 \%$ sampai $17,53 \%$. Kadar tanin atau dikenal juga dengan zat samak dari beberapa sampel yang diuji juga menunjukkan hasil yang lebih rendah dibandingkan dengan beberapa penelitian terdahulu dimana diperoleh kadar zat samak 34,79\% sampai $42 \%$. Kandungan kadar tanin berbanding terbalik dengan kadar katekin pada gambir. Kadar katekin gambir berkisar $14,76 \%$ sampai $54,97 \%$.

Kadar katekin terendah tersebut adalah dari lokasi Halaban, jika dibandingan dengan penelitian Ferita et al. (2012), kadar katekin dari lokasi Halaban mempunyai nilai kadar katekin yaitu $20,15 \%$, hasil ini juga menunjukkan nilai yang lebih rendah dibandingkan dengan beberapa lokasi yang digunakan sebagai sampel uji. Begitu juga dengan kadar katekin lokasi Siguntur adalah 46,87\% yang merupakan kadar katekin paling tinggi, sedangkan pada penelitian ini dari lokasi Siguntur Muda yaitu $45,73 \%$. Namun pada penelitian ini kadar katekin paling tinggi adalah lokasi Tarantang (Harau) dengan kadar katekin 54,97\%. 
Tabel 1. Data hasil analisis kualitas gambir dari sepuluh lokasi di Sumatera Barat.

\begin{tabular}{lccccc}
\hline \multicolumn{1}{c}{ Lokasi pengambilan sampel } & $\begin{array}{c}\text { Kadar } \\
\text { air }(\%)\end{array}$ & $\begin{array}{c}\text { Kadar } \\
\text { tanin (\%) }\end{array}$ & $\begin{array}{c}\text { Kadar ka- } \\
\text { tekin (\%) }\end{array}$ & $\begin{array}{c}\text { Kadar } \\
\text { abu (\%) }\end{array}$ & $\begin{array}{c}\text { Kadar zat tak } \\
\text { larut air (\%) }\end{array}$ \\
\hline Bukik Cubadak Lompek Lareh & 23,05 & 12,24 & 14,76 & 3,07 & 7,70 \\
Pangkalan & 10,93 & 24,16 & 36,22 & 5,60 & 26,40 \\
Lubuak Alai & 12,99 & 20,88 & 29,43 & 25,24 & 36,87 \\
Ilaok & 17,31 & 16,83 & 39,12 & 9,96 & 15,47 \\
Tarantang & 7,63 & 20,38 & 54,97 & 2,94 & 5,58 \\
Tanjuang Pati & 20,09 & 12,88 & 43,92 & 1,43 & 25,42 \\
Sari Lamak & 16,15 & 15,32 & 17,48 & 2,16 & 46,28 \\
Sialang & 23,16 & 13,28 & 51,62 & 6,22 & 7,10 \\
Siguntur Muda & 21,97 & 12,58 & 45,73 & 3,14 & 10,33 \\
Baruang-baruang Balantai & 22,31 & 16,78 & 50,53 & 3,30 & 9,20 \\
\hline Nilai menurut SNI 01-3391-2000 & Mak.16 & - & Min.50 & Mak.5 & Mak.10 \\
\hline
\end{tabular}

Kadar katekin pada gambir berkaitan dengan kadar bahan tak larut dalam air. Katekin bersifat tidak dapat larut dalam air. Namun berdasarkan analisis kadar zat tak larut dalam air menunjukkan hasil yang berbeda-beda pada setiap lokasi. Hal ini sesuai dengan pendapat Gnamm (1949), pada umumnya gambir murni tanpa bahan pengotor dari jenis blok dan butiran gambir yang berbeda adalah bahan tak larut air.

Kadar abu dapat disebabkan oleh dua hal yaitu mineral yang memang telah ada di dalam tanaman dan mineral yang terbawa oleh bahan bukan gambir yang sengaja ditambahkan oleh petani pengolah gambir. Kadar abu tertinggi terdapat pada lokasi Lubuak Alai yaitu mencapai $25,24 \%$. Hal ini menunjukkan bahwa pada gambir ini ditambahkan bahan bukan gambir pada proses pengolahan. Hal tersebut biasa dilakukan untuk meningkatkan rendemen dari gambir yang dihasilkan. Namun, hal ini menurunkan kualitas gambir yang dihasilkan. Jika dibandingkan dengan penelitian sebelumnya Kasim (2011) kadar abu gambir dari beberapa sampel berkisar antara 4,50\% sampai 5,98\%. Menurut Said et al. (2009), untuk memproduksi gambir dengan mutu yang baik menyarankan setiap proses pengolahan gambir harus dilakukan dengan baik dan meminimalkan timbulnya potensi yang dapat menurunkan mutu gambir. Dalam proses pembuatan gambir terdapat beberapa titik kritis yang mempengaruhi kualitas gambir dan berpotensi menurunkan kualitas gambir sehingga perlu perhatian khusus oleh produsen gambir.

Menurut Kasim (2011) titik kritis yang perlu diperhatikan pada beberapa tahapan proses dalam memproduksi gambir diantaranya: (1) pemanenan daun gambir, dimana daun yang terlalu tua dapat menurunkan kadar katekin dan rendemen, ketidak seragaman umur daun juga mempengaruhi variasi kadar katekin pada gambir. (2) Proses perebusan, penundaan perebusan daun gambir dan penggunaan air kelincuang (air sisa penirisan gambir di bawah alat pengempaan) dapat menyebabkan warna gambir yang dihasilkan menjadi kehitaman. Hal itu menurunkan kualitas gambir, dimana gambir yang diinginkan oleh ekportir adalah gambir dengan warna kuning kecoklatan. (3) Pengendapan, merupakan tahapan yang paling kritis, biasanya pengolah gambir menambahkan bahan pemberat seperti pasir dan tanah sehingga rendemen gambir yang dihasilkan lebih tinggi, pencampuran ini akan memberikan warna coklat terang. (4) Pengeringan dan penyimpanan, proses pengeringan yang tidak sempurna dan (5) penyimpanan yang kurang baik memungkinkan tumbuhnya kapang yang berpotensi menurunkan kualitas gambir.

Jika dibandingkandengan standar mutu gambir berdasarkan SNI 01-3391-2000 dari analisis kadar air terdapat tiga lokasi yang memenuhi standar mutu 1 yaitu Pangkalan, Tarantang dan Lubuak Alai, dimana kadar air maksimal untuk mutu 1 adalah $14 \%$. Analisis kadar abu menunjukkan tiga lokasi yang tidak memenuhi standar mutu gambir maksimal 5\% sementara tujuh lokasi lainnya memenuhi standar mutu (Tabel 1). Kadar tanin yang berfungsi sebagai bahan penyamak tidak dipersyaratkan pada mutu ini. Namun, gambir yang berasal dari Pangkalan, Lubuak Alai dan Tarantang diperkirakan dapat menghasilkan kulit 
Tabel 2. Data hasil analisis kimia dan sifat fisik kulit tersamak dengan bahan penyamak gambir dari sepuluh lokasi di Sumatera Barat.

\begin{tabular}{lcccc}
\hline \multicolumn{1}{c}{ Lokasi pengambilan sampel } & $\begin{array}{c}\text { Tanin } \\
\text { terikat } \\
(\%)\end{array}$ & $\begin{array}{c}\text { Derajat } \\
\text { penyamakan }(\%)\end{array}$ & $\begin{array}{c}\text { Kekuatan } \\
\text { tarik kulit } \\
\left(\mathrm{kg} / \mathrm{cm}^{2}\right)\end{array}$ & $\begin{array}{c}\text { Kemuluran } \\
(\%)\end{array}$ \\
\hline Bukik Cubadak Lompek Lareh & 21,48 & 27,35 & 517,53 & 22,10 \\
Pangkalan & 21,83 & 27,93 & 469,30 & 28,81 \\
Lubuak Alai & 11,43 & 12,91 & 400,77 & 34,98 \\
Ilaok & 19,91 & 24,85 & 455,43 & 23,79 \\
Tarantang & 13,87 & 16,11 & 270,46 & 34,10 \\
Tanjung Pati & 22,37 & 28,82 & 465,45 & 26,95 \\
Sari Lamak & 34,51 & 52,70 & 463,08 & 27,10 \\
Sialang & 21,01 & 26,60 & 478,29 & 29,75 \\
Siguntur Muda & 18,40 & 22,55 & 503,01 & 23,44 \\
Baruang-baruang Balantai & 21,58 & 27,51 & 536,36 & 20,73 \\
\hline Nilai SNI 0253-2009 & - & Min. 25 & Min. 225 & Mak. 70 \\
\hline
\end{tabular}

tersamak yang lebih baik dan memenuhi standar. Perkiraan ini didukung juga dengan hasil analisis kadar tanin gambir pada tiga lokasi ini cukup tinggi yaitu diatas $20 \%$.

\section{Kualitas Kulit Tersamak}

Hasil analisis kimia dan sifat fisik kulit tersamak yang disamak dengan gambir dari sepuluh lokasi dapat dilihat pada Tabel 2. Analisis kimia terdiri tanin terikat dan derajat penyamakan, sedangkan sifat fisik kulit tersamak terdiri dari kekuatan tarik dan kemuluran kulit.

Kadar tanin terikat merupakan jumlah tanin yang berikatan dengan kolagen kulit. Hasil analisis tanin terikat pada kulit dihitung berdasarkan metode SNI 06-0463-1989 yaitu hasil pengurangan dari komponen seperti kadar air, kadar zat kulit mentah, kadar lemak, kadar abu dan kadar zat larut dalam air. Tanin terikat dari kulit tersamak yang di samak dengan gambir dari sepuluh lokasi menunjukkan hasil yang bervariasi. Secara umum kadar tanin terikat terlihat sejalan dengan derajat penyamakan kulit tersamak. Hal ini terlihat pada kadar tanin terikat terendah $(11,43 \%)$ yaitu penggunaan gambir dari lokasi Lubuak Alai didapatkan derajat penyamakan $12,91 \%$, sedangkan kadar tanin terikat tertinggi terdapat pada penggunaan gambir dari Sari Lamak yaitu 34,51\% dengan derajat penyamakan $52,70 \%$. Menurut Kasim et al. (2014) analisis derajat penyamakan bertujuan untuk mengetahui jumlah bahan penyamakan yang berikatan didalam jaringan serat kolagen sehingga terjadi ikatan kimia. Terjadinya ikatan ini ditentu- kan oleh struktur fisik dan kimia kulit yang akan disamak serta bahan penyamak yang digunakan.

Sifat fisik kulit di pengaruhi oleh sifat kimia dari kulit tersamak seperti kadar air, tanin terikat dan derajat penyamakan. Menurut Sahubawa et al. (2011), kandungan air didalam kulit tersamak mempengaruhi tingkat kematangan serat protein kolagen kulit, karena air yang berikatan pada sudut-sudut heliks yang mengakibatkan rendahnya kekuatan tarik dan kekuatan sobek serta ikatan antara serat kolagen dan bahan penyamak menentukan kekuatan tarik kulit.

Gambir merupakan bahan penyamak yang baik. Menurut Gnamm (1949) gambir digolongkan sebagai zat samak terbaik. Larutan penyamak yang dibuat dari gambir cepat mencapai optimal dan larutannya keruh stabil. Hasil penyamakan dengan gambir menghasilkan warna kuning menarik, lembut dan bila dipegang terasa ringan dan halus. Hal ini juga didukung oleh beberapa hasil penelitian sebelumnya (Kasim et al., 2012; Kasim et al., 2013; Kasim et al., 2014) bahwa gambir adalah sebagai bahan penyamak yang sangat baik, dimana semua hasil penelitian dengan berbagai macam konsentrasi dan berbagai pelakuan menunjukkan hasil yang memenuhi standar industri.

\section{Hubungan Kualitas Gambir dengan Kualitas Kulit Tersamak}

Untuk mengetahui hubungan antara beberapa parameter gambir (x) yang terdiri atas kadar tanin, kadar katekin, kadar abu dan kadar zat tak larut da- 
Tabel 3. Rekapitulasi regresi hubungan antara kualitas gambir dengan analisis kulit tersamak.

\begin{tabular}{lcc}
\hline Parameter yang dihubungkan & Nilai r & Kesimpulan hubungan \\
\hline Kadar tanin gambir dengan tanin terikat & 0,980 & Sangat erat \\
Kadar tanin dengan derajat penyamakan & 0,983 & Sangat erat \\
Kadar tanin dengan kekuatan tarik & 0,804 & Rendah \\
Kadar katekin dengan tanin terikat & 0,967 & Sangat erat \\
Kadar katekin dengan derajat penyamakan & 0,953 & Sangat erat \\
Kadar katekin dengan kekuatan tarik & 0,752 & Rendah \\
Kadar abu dengan tanin terikat & 0,852 & Sangat erat \\
Kadar abu dengan derajat penyamakan & 0,942 & Sangat erat \\
Kadar abu dengan kekuatan tarik & 0,793 & Rendah \\
Kadar zat tak larut air dengan tanin terikat & 0,747 & Rendah \\
Kadar zat tak larut air dengan derajat penyamakan & 0,942 & Sangat erat \\
Kadar zat tak larut air dengan kakuatan tarik & 0,837 & Sangat erat \\
\hline
\end{tabular}

lam air dengan karakteristik kulit tersamak $\left(\mathrm{Y}_{1}\right.$ dan $\mathrm{Y}_{2}$ ) digunakan analisis regresi linier. Rekapitulasi analisis regresi beberapa kualitas gambir dengan kualitas kulit tersamak dapat dilihat pada Tabel 3. Hasil perhitungan regresi menunjukkan hubungan yang sangat erat antara kadar tanin gambir dengan tanin terikat, derajat penyamakan dan kekuatan tarik kulit tersamak. Hal ini ditunjukkan dengan nilai $\mathrm{r}$ (koofisien korelasi) berturut-turut sebesar $0,980,0,983$ dan 0,804 . Hubungan yang sangat erat antara kadar katekin dan kadar abu dengan kadar tanin terikat dan derajat penyamakan dengan nilai $r$ berturut-turut sebesar 0,967 dan 0,953 , namun menunjukkan korelasi yang rendah terhadap kekuatan tarik dengan nilai $\mathrm{r} 0,752$. Hubungan antara kadar abu gambir dengan tanin terikat dan derajat penyamakan kulit tersamak menunjukkan

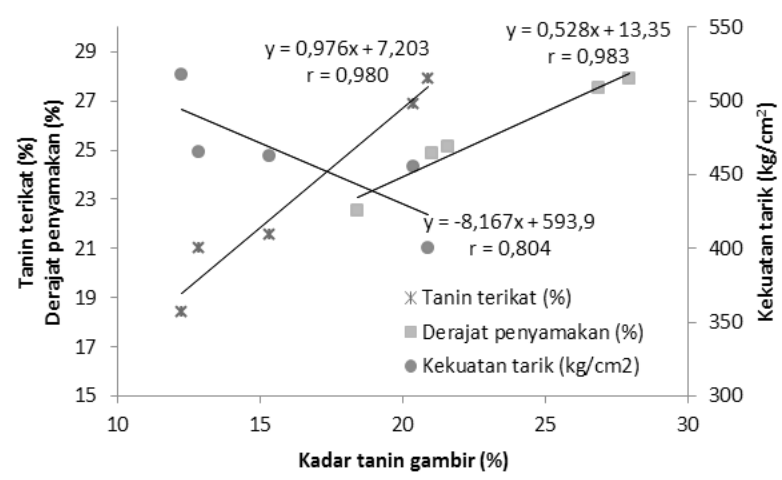

Gambar 1. Grafik hubungan antara kadar tanin gambir dengan kadar tanin terikat, derajat penyamakan dan kekuatan tarik kulit tersamak. hubungan yang sangat erat dengan nilai $r$ berturutturut sebesar 0,852 dan 0,943, namun menunjukkan hubungan yang rendah terhadap kekuatan tarik dengan nilai $r=0,793$. Hubungan yang erat juga ditunjukkan antara kadar zat tak larut air gambir dengan derajat penyamakan dan kekuatan tarik kulit dengan dengan $r$ berturut-turut sebesar 0,942 dan 0,837, namun menunjukkan hubungan yang rendah terhadap tanin terikat pada kulit tersamak.

\section{Hubungan Antara Kadar Tanin dengan Kua- litas Kulit Tersamak}

Pada Gambar 1 ditampilkan grafik hubungan antara kadar tanin gambir dengan kadar tanin terikat, derajat penyamakan dan kekuatan tarik kulit tersamak yang dihasilkan.

Hasil analisis regresi menunjukkan hubungan yang erat antara kadar tanin gambir dengan kadar tanin terikat pada kulit tersamak $(r=0,980)$, dimana semakin meningkat kadar tanin di dalam gambir sebagai bahan penyamak maka akan meningkatkan kadar tanin terikat didalam kulit tersamak. Begitu juga dengan derajat penyamakan yang menunjukkan peningkatan seiring dengan meningkatnya kadar tanin yang terdapat pada bahan penyamak gambir, namun dengan nilai $\mathrm{r}$ relatif rendah $(\mathrm{r}=0,804)$. Karakteristik kimia kulit tersamak memberikan pengaruh terhadap sifat fisik kekuatan tarik kulit tersamak. Dalam hal ini, semakin tinggi kadar tanin yang berikatan dengan kulit menunjukkan kekuatan tarik kulit yang semakin meningkat dengan nilai $r=0,840$.

Dari Gambar 1 tersebut dapat disimpulkan bahwa semakin tinggi kadar tanin gambir maka 


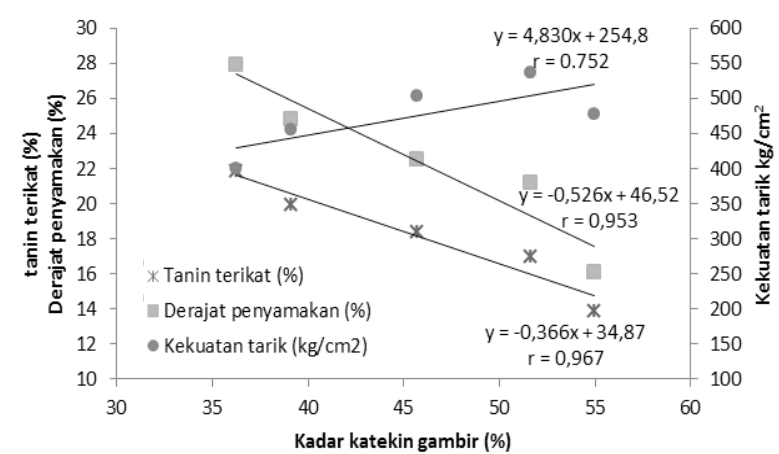

Gambar 2. Grafik hubungan antara kadar katekin gambir dengan kadar tanin terikat, derajat penyamakan, dan kekuatan tarik kulit tersamak yang dihasilkan.

kadar tanin terikat pada kulit tersamak akan semakin meningkat pula dan sekaligus juga dapat menjelaskan bahwa gambir akan semakin baik hasil penyamakannya jika kadar taninnya tinggi, sebaliknya terlihat juga penurunan kekuatan kulit tersamak jika kadar tanin gambir semakin rendah.

\section{Hubungan Antara Kadar Katekin dengan Kualitas Kulit Tersamak}

Pada Gambar 2 ditampilkan grafik hubungan antara kadar katekin gambir dengan kadar tanin terikat, derajat penyamakan dan kekuatan tarik kulit tersamak yang dihasilkan.

Hubungan antara kadar katekin dengan tanin terikat kulit menunjukkan bahwa semakin rendah kadar katekin pada bahan penyamak akan menghasilkan kadar tanin terikat pada kulit meningkat. Hal ini menunjukkan bahwa kadar katekin di dalam penyamak tidak bereaksi dengan kulit. Katekin bukan tergolong dari zat samak yang akan membentuk ikatan dengan kolagen pada kulit walaupun katekin adalah monomer dari tanin. Demikian juga halnya dengan derajat penyamakan kulit, juga menunjukkan hubungan yang berbading terbalik dengan kadar katekin, dimana semakin tinggi kadar katekin pada gambir menunjukkan semakin rendah derajat penyamakan kulit tersamak. Jika diamati hubungan antara kadar katekin dengan sifat fisik kekuatan tarik kulit tersamak bahwa, kadar katekin gambir yang tinggi menghasilkan kekuatan tarik yang lebih tinggi. Hal ini bertolak belakang dengan kadar tanin gambir yang tinggi akan menghasilkan kekuatan tarik kulit tersamak yang lebih rendah dan diperkirakan karena reaksi kimia yang terjadi antara kulit dengan tanin akan menyebabkan kekuatan tarik

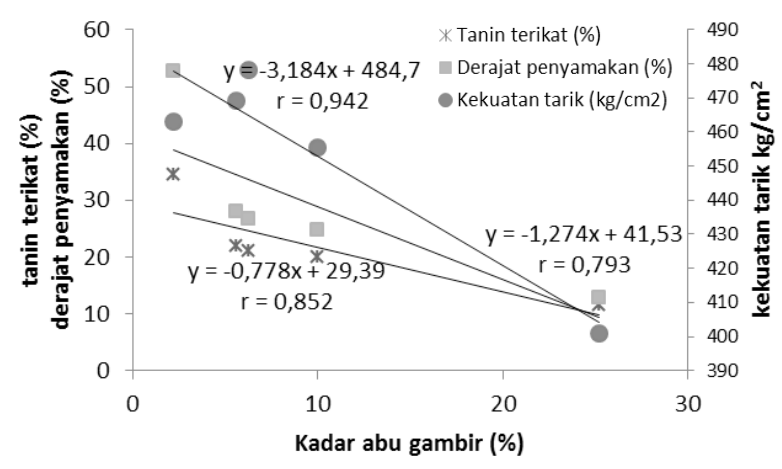

Gambar 3. Grafik hubungan antara kadar abu gambir dengan kadar tanin terikat, derajat penyamakan dan kekuatan tarik kulit tersamak yang dihasilkan.

kulit tersamak menjadi berkurang. Dari Gambar 2 dapat diketahui bahwa untuk penyamakan kulit lebih baik digunakan gambir dengan kadar katekin yang relatif rendah.

\section{Hubungan Antara Kadar Abu dengan Kualitas Kulit Tersamak}

Pada Gambar 3 ditampilkan grafik hubungan antara kadar abu gambir dengan kadar tanin terikat, derajat penyamakan dan kekuatan tarik kulit tersamak yang dihasilkan.

Hubungan antara kadar abu pada gambir sebagai bahan penyamak dengan kadar tanin terikat kedalam kulit tersamak menunjukkan hubungan yang erat, dimana semakin tinggi kadar abu di dalam bahan penyamak akan menurunkan kadar tanin terikat di dalam kulit. Begitu juga dengan derajat penyamakan kulit tersamak juga menujukkan hal yang selaras dengan kadar tanin terikat pada kulit $(\mathrm{r}=0,942)$. Kadar abu yang tertinggi didalam gambir diperkirakan karena adanya bahan bukan gambir yang ditambahkan kedalam gambir. Semakin tinggi kadar abu didalam bahan penyamak mengakibatkan kadar zat samak didalam bahan penyamak akan menjadi rendah, sehingga kadar tanin terikat dan derajat penyamakan pada kulittersamakjugamenunjukkan hasil yang rendah. Sifat fisik kekuatan tarik kulit tersamak menunjukkan hasil yang berbanding terbalik dengan kadar abu gambir, semakin tinggi kadar abu pada bahan penyamak menunjukkan kekuatan tarik kulit tersamak semakin rendah. Hal ini juga diperlihatkan oleh kulit tersamak semakin kaku.

Dari Gambar 3 dapat diketahui bahwa semakin tinggi kadar abu pada gambir sebagai 


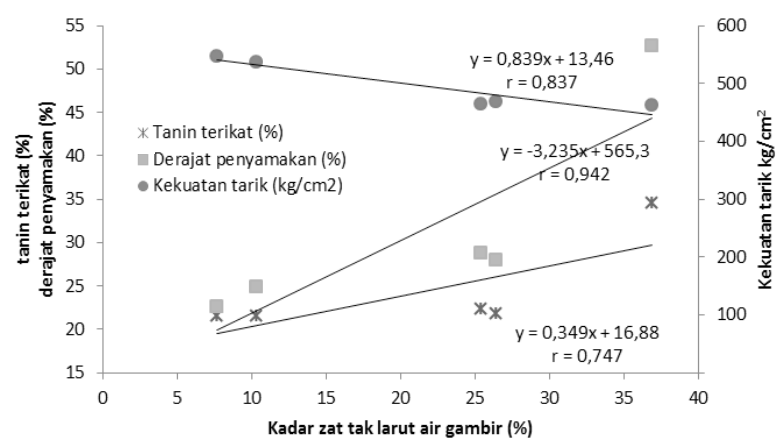

Gambar 4. Grafik hubungan antara kadar zat tak larut air gambir dengan kadar tanin terikat, derajat penyamakan dan kekuatan tarik kulit tersamak.

bahan penyamak kulit akan menurunkan kadar tanin terikat, derajat penyamakan kulit tersamak dan kadar abu yang tinggi dapat menyebabkan kekuatan tarik kulit tersamak juga lebih rendah.

\section{Hubungan Kadar Zat Tak Larut Dalam Air dengan Kualitas Kulit Tersamak}

Pada Gambar 4 ditampilkan grafik hubungan antara kadar zat tak larut air gambir dengan kadar tanin terikat, derajat penyamakan dan kekuatan tarik kulit tersamak yang dihasilkan.

Kadar zat tak larut air pada gambir merupakan bahan-bahan selain dari tanin seperti katekin. Menurut Gnamm, (1949) katekin menyebabkan bias pada analisis zat samak atau tanin. Oleh sebab itu, jika kadar zat tak larut air gambir semakin meningkat maka kadar tanin terikat pada kulit tersamak seharusnya juga semakin berkurang. Namun, pada penelitian ini menunjukkan hasil yang sebaliknya, dimana semakin tinggi kadar zat tak larut air gambir maka kadar tanin terikat dan kadar derajat penyamakan kulit tersamak juga menunjukkan peningkatan. Dari Gambar 4 dapat dilihat bahwa tidak terdapat korelasi antara kadar zat tak larut air dengan tanin terikat dan derajat penyamakan kulit tersamak. Dengan demikian kadar zat tak larut dalam air dari gambir tidak dapat dijadikan sebagai dasar untuk justifikasi untuk menyatakan baik tidak baiknya gambir untuk dijadikan bahan penyamak kulit.

\section{KESIMPULAN}

Berdasarkan hasil penelitian dapat disimpulkan bahwa: Hasil analisis gambir yang diambil dari sepuluh lokasi di sentra produksi gambir di Sumatera Barat menunjukkan hasil yang bervariasi yang terdiri dari kadar tanin, kadar katekin, ka- dar abu dan kadar zat tak larut air. Hasil analisis kimia dan pengamatan kulit tersamak yang disamak dengan menggunakan gambir dari sepuluh lokasi tersebut memenuhi standar kulit tersamak SNI 0253-2009, kecuali tiga lokasi yang tidak memenuhi standar dari parameter derajat penyamakan yaitu Lubuak Alai, Tarantang dan Siguntur Muda. Hubungan antara komposisi kimia gambir yang terdiri dari kadar tanin, kadar katekin, kadar abu menunjukkan hubungan yang sangat erat dengan kadar tanin terikat, kadar derajat penyamakan dan kekuatan tarik kulit tersamak. Namun, hubungan antara kadar katekin dan kadar abu gambir dengan kekuatan tarik kulit tersamak menunjukkan korelasi yang rendah.

\section{UCAPAN TERIMAKASIH}

Ucapan terimakasih disampaikan kepada Dirjen Pendidikan Tinggi (DIKTI) yang telah membiayai penelitian ini melalui PENPRINAS MP3EI dengan kontrak No.07/UN.16/PL/MP3EI/ I/2014 dan kepada Balai Besar Kulit Karet dan Plastik (BBKKP) Yogyakarta yang telah membantu dalam pengujian sampel kulit tersamak.

\section{DAFTAR PUSTAKA}

Achmad, A., Kassim, J., Suan, T. K., Amat, R. C. \& Seey, T. L. (2012). Equilibrium, kinetic and thermodynamic studies on the adsorption of direct dye onto a novel green adsorbent developed from Uncaria gambier extract. Journal of Physical Science, 23(1), 1-13.

BSN (Badan Standardisasi Nasional). (2009). Standar Nasional Indonesia SNI 0253 :2009. Kulit bagian atas alas kaki-kulit kambing. Jakarta, Indonesia: BSN.

BSN (Badan Standarisasi Nasional). (2000). Standar Nasional Indonesia SNI 01-3391-2000. Syarat mutu gambir. Jakarta, Indonesia: BSN.

BSN (Badan Standarisasi Nasional). (1989). Standar Nasional Indonesia SNI 06-0463-1989. Kulit lapis domba/kambing samak kombinasi. Jakarta, Indonesia: BSN.

BSN (Badan Standarisasi Nasional). (1989). Standar Nasional Indonesia SNI 06-0563-1989. Kulit tersamak, Cara uji kadar abu. Jakarta, Indonesia: BSN.

BSN (Badan Standarisasi Nasional). (1989). Standar Nasional Indonesia SNI 06-0644-1989. Cara uji dalam kadar air kulit. Jakarta, Indonesia: BSN.

BPS (Badan Pusat Statistik) Provinsi Sumatera Barat. (2008). Statistik perdagangan luar negeri Sumatera Barat. Padang, Indonesia: BPS Provinsi Sumatera Barat.

Buletin Provinsi Sumbar. (2011). Komoditi gambir 
sumbar dapat perhatian. ANTARA Sumbar.

Fengel, F. \& Wegener, D. (1995). Kayu, kimia, ultrastruktur, reaksi-reaksi. Harjono (Penyadur) dan S. Prawirohatmojo (Ed). Yogyakarta, Indonesia: Gajah Mada University Press.

Ferita, I., Jamsari, J., Suliansyah, I. \& Gustian, G. (2012). Studi hubungan karakter morfologi anatomi dan molekuler terkait potensi kadar katekin pada tanaman gambir (Uncaria gambir (Hunter) Roxb.). http://pasca.unand.ac.id/id/wpcontent/uploads/2012/01/Artikel-Disertasi-IstinoFerita.pdf, diakses tanggal 9 Maret 2015.

Gnamm, L. A. (1949). Die Gerbstoffe und Gerbmittel. Stuttgart, Jerman: Wissenschaffttliche Verrlanggsellschaft M.B.H.

Kasim, A. (2011). Proses produksi dan industri hilir gambir. Jakarta, Indonesia: Universitas Andalas Press.

Kasim, A., Novia, D., Mutiar, S., \& Pinem, J. (2013). Karakteristik kulit kambing pada persiapan penyamakan dengan gambir dan sifat kulit tersamak yang dihasilkan. Majalah Kulit Karet dan Plastik, 29(1), 01-12.

Kasim, A., Novia, D., Mutiar, S., \& Efendi, A. (2014). Dimishing chromium use on combined cromgambier tanning proses upon the characteristics of tanned leather. Journal of Animal Science and Teknology, 37(1), 24-29.
Kuentzel, A. (1955). Gerbereichemisches Taschenbuch. Leipzig, Jerman: Verlag von Theodor Steinkopff.

Lehnen, R. (2006). Test metods for determining formaldehyde content and formaldehyde emissions of wood based panels. In Cost E 49 Training course "Testing and evaluation of emissions from wood based material". Hamburg, Jerman.

Linkenheil, K. \& Steinmann, K. H. (1998). Gambir processing and marketing in West Sumatera. Padang, Indonesia: Departemen Perindustrian dan Perdagangan.

Said, E. G., Khaswar, S., Etik, M, Alexi, H., Nur, A. E., Dwi, L. R., Ratih, P., Aang, A. A., \& Aditya, H. (2009). Agroindustri dan bisnis gambir Indonesia. Bogor, Indonesia: Kampus IPB Taman Kencana.

Sahubawa, L., Pertiwiningrum, A., \& Pamungkas, A. T. (2011). Pengaruh kombinasi bahan penyamak formalin dan syntan terhadap kualitas kulit ikan pari tersamak. Majalah Kulit, Karet dan Plastik, 27(1), 38-45.

Ullmanns Encyklopedie. (1978). Technischen Chemie Band 16. Lagerwerkstoff bis Milch. Weinheim, Jerman: Verlang Chemie. 
